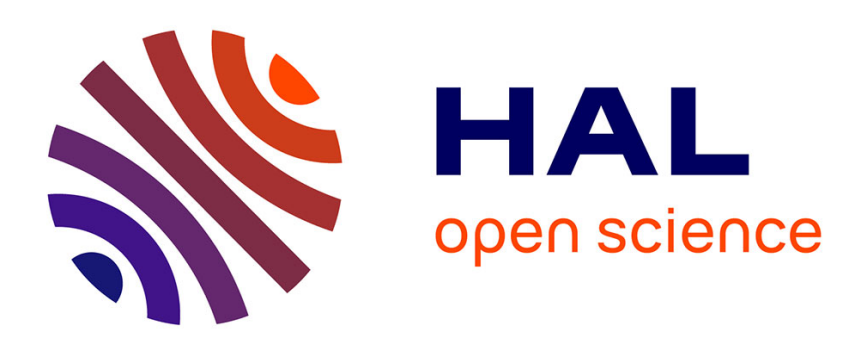

\title{
The influence of water-content gradient and structure anisotropy on soil compressibility \\ Jérôme Guerif
}

\section{To cite this version:}

Jérôme Guerif. The influence of water-content gradient and structure anisotropy on soil compressibility. Journal of Agricultural Engineering Research, 1984, 29, pp.367-374. hal-02727293

\section{HAL Id: hal-02727293 \\ https: / hal.inrae.fr/hal-02727293}

Submitted on 2 Jun 2020

HAL is a multi-disciplinary open access archive for the deposit and dissemination of scientific research documents, whether they are published or not. The documents may come from teaching and research institutions in France or abroad, or from public or private research centers.
L'archive ouverte pluridisciplinaire HAL, est destinée au dépôt et à la diffusion de documents scientifiques de niveau recherche, publiés ou non, émanant des établissements d'enseignement et de recherche français ou étrangers, des laboratoires publics ou privés. 


\title{
The Influence of Water-content Gradient and Structure Anisotropy on Soil Compressibility
}

\author{
J. GUÉRIF*
}

\begin{abstract}
Most attempts to model compaction have used simplistic homogeneous and isotropic profiles of soil structurc, and sometimes water content. However, anisotropy of structure and water content are always found in real agricultural soils.

In this paper, the distributions with depth of initial water content and bulk density are taken into account to analyse the compaction process of soil assuming that the soil profile may be partitioned in a multilayer system, where each layer is defined as homogeneous and isotropic in regard to its mechanical behaviour.

In the first field experiment, bulk density mcasurements, after whecling at different tyre inflation pressure, showed that a slight topsoil drying, prior to wheeling, enhances the effectiveness of low pressure tyres in preventing excess compaction.

In the sccond field experiment, compression curves, obtained in situ with a sinkage plate apparatus combined with a gamma-ray probe, showcd that it was possible to analyse the compaction process of a multilaycr system, defined by its bulk density, considering the compression process of the wholc system as the result of an interaction between the compressibility of each layer.
\end{abstract}

\section{Introduction}

Both the simplification and the intensification of cultivation systems increase the probability for soils to be at low water suction at the time of both seedbed and harvest traffic. This development, associated with the increasing weight and power of agricultural vehicles, intensifies the risks of soil compaction and damage to soil structure.

Current knowledge of soil compaction by agricultural vehicles has been reviewed by Soane, ${ }^{1}$ and the need for a model for predicting compaction under wheels is clearly demonstrated, but it is evident that a general theory is a long way off. Most attempts to model compaction have used simplistic homogeneous and isotropic profiles of soil structure, and sometimes soil water content. Anisotropy of structure and water content are always found in real agricultural soils.

In this paper two of the main factors influencing the compaction process are studied, according to their distribution with depth. The first experiment illustrates the effect of the water-content profile. The importance of soil water status has been emphasized by many authors ${ }^{2,3}$ and the effect of water content on soil compactability has been examined in many laboratory studies, for example, References (4) (7). However, in most field experiments water status is described by the average value of the water content of the whole compacted layer. The second experiment shows the effect of the vertical distribution of initial bulk density through the topsoil and subsoil. The importance of an interaction between different layers of topsoil and subsoil when compacted has been postulated by Fekete ${ }^{8}$ and profiles of initial density and strength have been used in other models. ${ }^{9}$

*Institut National de la Recherche Agronomique, Centre de Recherches Agronomigues d'Avignon, Station de Science du Sol. B.P. 21 , 84140 Montfavet. France

Received 10 November 1983 ; accepted in revised form 12 March 1984

Paper psesented at AG ENG 84, Cambricge, U.K., 1-5 April 1984 
TABLE I

Particle-sizc distribution of soils

\begin{tabular}{l|c|c|c|c|c|c|c}
\hline \multirow{2}{*}{$\begin{array}{c}\text { Soil } \\
\text { location }\end{array}$} & Clay & \multicolumn{2}{|c|}{ Silt } & \multicolumn{2}{c|}{ Sand } & \multirow{2}{*}{$\begin{array}{c}\text { Organic } \\
\text { carbon, } \%\end{array}$} & $\begin{array}{c}\text { Plasticity } \\
\text { index, } \%\end{array}$ \\
\cline { 2 - 7 } & $\begin{array}{c}<\mu \mathrm{m} \\
\%\end{array}$ & $\begin{array}{c}2-20 \mu \mathrm{m} \\
\%\end{array}$ & $\begin{array}{c}20-50 \mu \mathrm{m} \\
\%\end{array}$ & $50-200 \mu \mathrm{m}$ & $200-2000 \mu \mathrm{m}$ & \\
\hline Les Vignères & 46.7 & 31.3 & 8.0 & $\begin{array}{c}11.2 \\
7.7\end{array}$ & $\begin{array}{c}2.08 \\
2.0\end{array}$ & $\begin{array}{c}1.03 \\
0.99\end{array}$ & 26.6 \\
Boigneville & 24.3 & 28.1 & 37.9 & 13.4 \\
\hline
\end{tabular}

TABLE 2

Whecl and tractor specifications

\begin{tabular}{|c|c|c|c|c|c|c|c|}
\hline \multirow{2}{*}{ Power } & \multirow{2}{*}{$\begin{array}{l}\text { Forwald } \\
\text { speed }\end{array}$} & \multirow{2}{*}{ Wheel } & \multirow{2}{*}{ Load, $k N$} & \multirow{2}{*}{ Tyre size } & \multirow{2}{*}{ Ply rating } & \multicolumn{2}{|c|}{$\begin{array}{c}\text { Recommended inflation } \\
\text { pressure, } k P^{2} a\end{array}$} \\
\hline & & & & & & $\max$ & $\min$ \\
\hline $\begin{array}{l}41 \mathrm{~kW} \text { DIN } \\
\text { at } 2500 \mathrm{rcv} / \mathrm{min}\end{array}$ & $0.8 \mathrm{~m} / \mathrm{s}$ & $\begin{array}{l}\text { Front } \\
\text { Rear }\end{array}$ & $\begin{array}{l}4 \cdot 42 \\
7 \cdot 80\end{array}$ & $\begin{array}{l}7 \cdot 50-16 \\
12 \cdot 4-38\end{array}$ & $\begin{array}{l}6 \\
6\end{array}$ & $\begin{array}{l}250 \\
150\end{array}$ & $\begin{array}{l}80 \\
80\end{array}$ \\
\hline
\end{tabular}

\section{Material and methods}

Two field experiments were carried out in July 1980 and May 1982. They are reported separately because of differences in experimental procedures.

\subsection{Influence of the water profile}

This factor was studied on a clayey soil (at Les Vignères) whose characteristics are given in Table 1. Plots were tilled twice to a depth of about $20 \mathrm{~cm}$ with a rotary digging machine, "the final thickness of the tilled layer being about $32 \mathrm{~cm}$. Sprinkler irrigation was used to raise the soil water content close to field capacity; subsequently differences in the water-content profiles of two plots were obtained by either allowing evaporation (plot 2) or not (plot 1). A rotary digger machine was used to provide a sufficiently deep isotropic structure with small structural inits to permit detection of phenomena and enable meaningful measurement of bulk density. A tractor (Table 2) was used to apply compactive stresses at three inflation pressures in both front and rear wheel tyres $(50,125$ and $200 \mathrm{kPa})$ and at constant wheel loading. Modifications to the soil structure were measured by obtaining profiles of initial and final dry bulk density with gamma-ray transmission equipment having a twin probe separation of about $14.5 \mathrm{~cm}^{10}$ and a maximum depth of measurement of $40 \mathrm{~cm}$. The soil collected from access holes augered for insertion of the twin probe was used to determine gravimetric water content. Surface sinkage (depth, width and cross sectional area of ruts) was measured by a needle relief meter with $2.5 \mathrm{~cm}$ spacing. Dry bulk density was measured, with four-fold replication, before and after wheeling, at $2.5 \mathrm{~cm}$ intervals from $5 \mathrm{~cm}$ to $35 \mathrm{~cm}$ depth.

\subsection{Influence of structure anisotropy}

The second experiment was carried out on a silt loam described in Table 1 (Boigneville). Field compaction tests were made in the plots of a long-term cultivation experiment, started in 1970 , and with a maize-winter wheat rotation in which different tillage techniques were compared, namely, mouldboard ploughing $(25 \mathrm{~cm})$, shallow cultivation $(10 \mathrm{~cm})$ and direct drilling. 


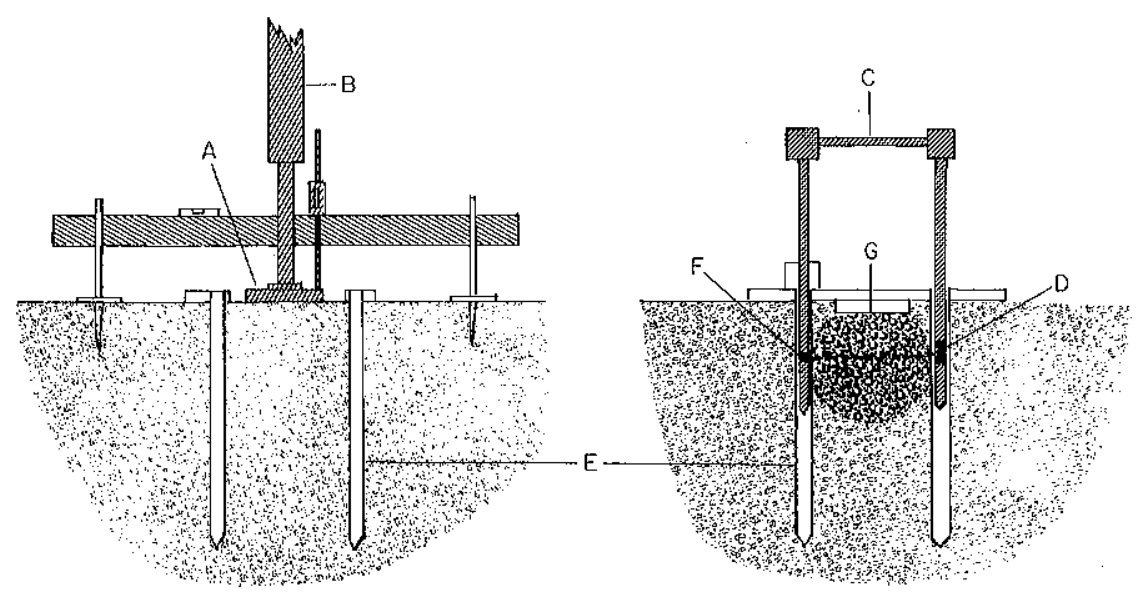

Fig. 1. Diagram of the sinkage plate apparatus combined with a gamma-ray transmission equipment. $A, P l a t e ; B$, hydraulic jack; $C$, gamma-ray transmission equipment; $D$, detector; $E$, aluminium access tubes; $F$, source ${ }^{137} C s ; G$, compacted zone

As an example, the results obtained in the shallow cultivated plots are reported here. The experiment took place in spring, immediately after maize seedbed preparation. The soil was at field capacity and there was no variation in water content with depth.

Compaction was carried out using a sinkage plate apparatus combined with gamma-ray transmission equipment for measuring bulk density variations (Fig. 1). The apparatus was fixed on the threepoint linkage of a tractor. A $15 \mathrm{~cm}$ dia. plate (A) was driven into the soil by a hydraulic jack (B). The average soil-plate contact pressure was kept constant during compression by maintaining constant oil pressure in the piston body using a relief valve. The surface pressures used were $200,300,400,600$ and $800 \mathrm{kPa}$. For each pressure, the loading time was $30 \mathrm{~s}$. The complete set of pressures was applied successively at the same location.

Initially and at each pressure, profiles of bulk density were obtained with gamma-ray transmission equipment $(C)$ having a twin probe separation of $30 \mathrm{~cm}$ with a maximum depth measurement of $50 \mathrm{~cm}$. This equipment is based on a scintillation detector (D) and photomultiplier. ${ }^{11}$ Aluminium access tubes (E) were set into parallel holes made by the auger, at the same time samples were taken and oven-dried $\left(105^{\circ} \mathrm{C}\right)$ to determine gravimetric moisture content and dry bulk density. The compaction process examined at six locations in a shallow cultivated plot is reported. The profiles of bulk density are measured at $3 \mathrm{~cm}$ intervals from $3 \mathrm{~cm}$ to $39 \mathrm{~cm}$ depth.

\subsection{Pore space expressions}

Dry bulk density $\left(\rho_{d}\right)$ and void ratio $(e)$ are used in this paper to express the compaction responses in the soil. Soil pore space can be partitioned into:

(1) intra-aggregate or textural pore space which is due mainly to the packing state of the mineral particles ${ }^{12}$ and

(2) inter-aggregate or structural pore space which results from arrangement of structural elements (aggregates, crumbs, ...) created by tillage and/or natural cracking.

When expressed as void ratio, it can be written

$$
e=e_{t}+e_{\mathrm{s}}
$$

where $e$ is the total void ratio and $e_{t}$ and $e_{s}$ are the textural and structural void ratios, respectively. 
For a given soil, textural pore space varies according to its swelling and shrinkage bchaviour. ${ }^{13}$ It can be assumed that for numerous types of soil (particularly for clayey soils) and for the pressures observed in agricultural conditions, textural pore space is not affected by under-wheel compaction. Consequently, structural void ratio is a convenient way of expressing compressible pore space and avoids complications due to swelling and shrinkage, in the study of pore space modifications by underwheel compaction. ${ }^{7}$

\section{Results}

\subsection{Influence of the water-content profile}

Two plots with different water content profiles are compared (Fig. 2). At plot 1 the topsoil layer was considered to have a homogeneous and isotropic water content. After wheel compaction, there was no effect of inflation pressure in any of the three treatments [Fig. 3 (left)]. Structural void ratio was close to zero and reached the structural void ratio of the subsoil. Mean rut depths were not significantly different. The under-wheel soil bulk density was, after one pass, the same as it had been prior to tillage.

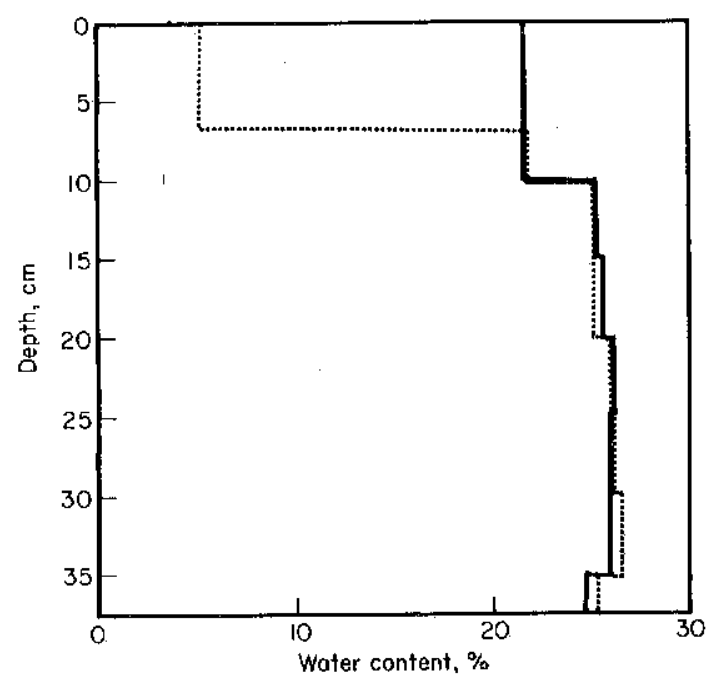

Fig. 2, Distribution with depth of the water content in the two experimental plots. _, Plot $1, \cdots \cdots$, Plot 2

At plot 2, the tilled layer is considered as a "two layer" system consisting of an air dried layer $(7 \mathrm{~cm}$ depth) overlaying a layer at field capacity. The final structural void ratio decreased, and mean rut depth increased, with increasing tyre inflation pressure [Fig. 3(right)]. The presence of the thin surface layer of dry soil appears to offer protection against compaction and also to enhance the effectiveness of low-pressure tyres in reducing compaction.

\subsection{Influence of structure anisotropy}

The profile of initial dry bulk density (Fig. 4), together with field observations allow definition of three layers, namely, layer A, the rotary tilled layer, depth $10 \mathrm{~cm}$ approximately; layer $\mathrm{B}$, between the lower limit of $\mathrm{A}$ and the lower limit of the former ploughed layer; and layer $\mathrm{C}$, the undisturbed subsoil. 

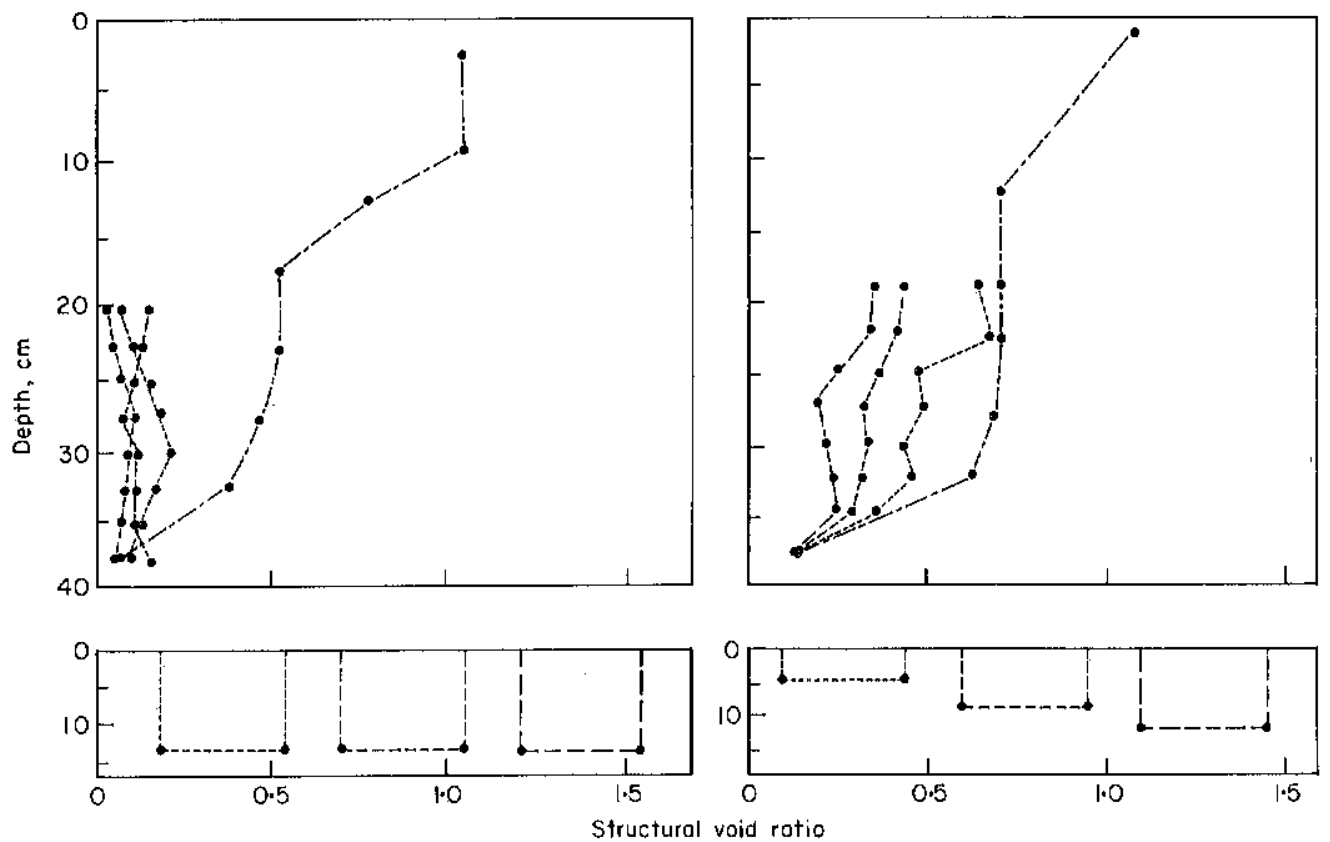

Fig. 3. Effect of inflation pressure of tyres on mean rut depth and distribution with depth of structural void ratio. (Left) Plot 1; (right) plot 2.-.-, Initial; -.-, $50 \mathrm{kPa} ;---, 125 \mathrm{kPa} ;--, 200 \mathrm{kPa}$

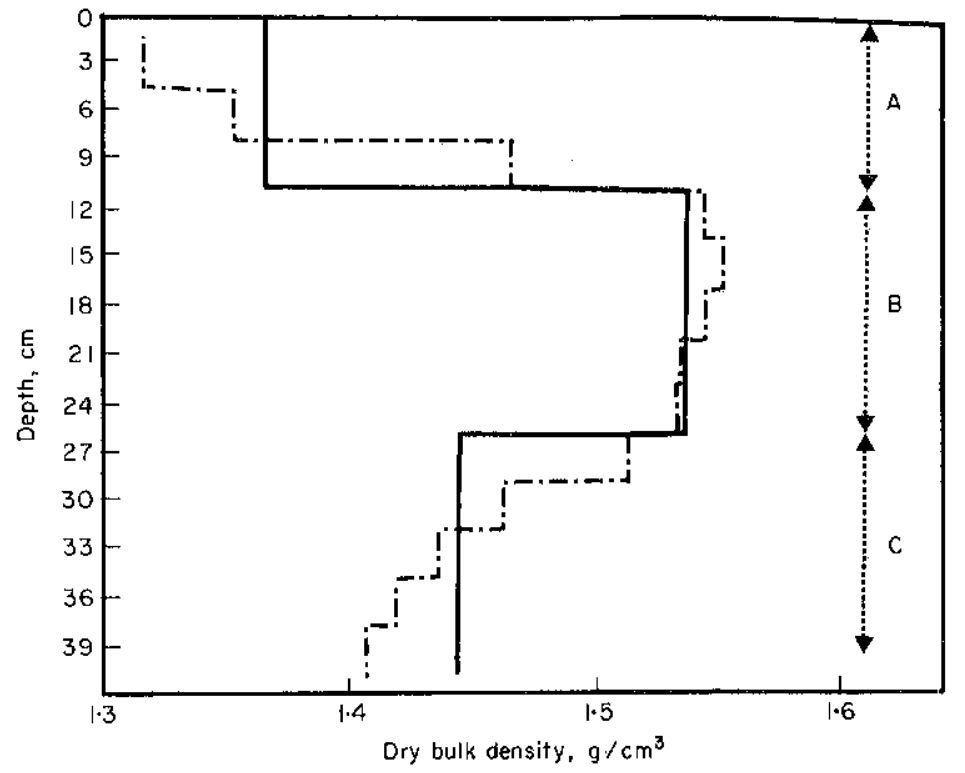

Fig. 4. Simplification of a detailed bulk density profile into a three-layer system. Initial profile. -.-, Measured values; $\longrightarrow$ mean values 


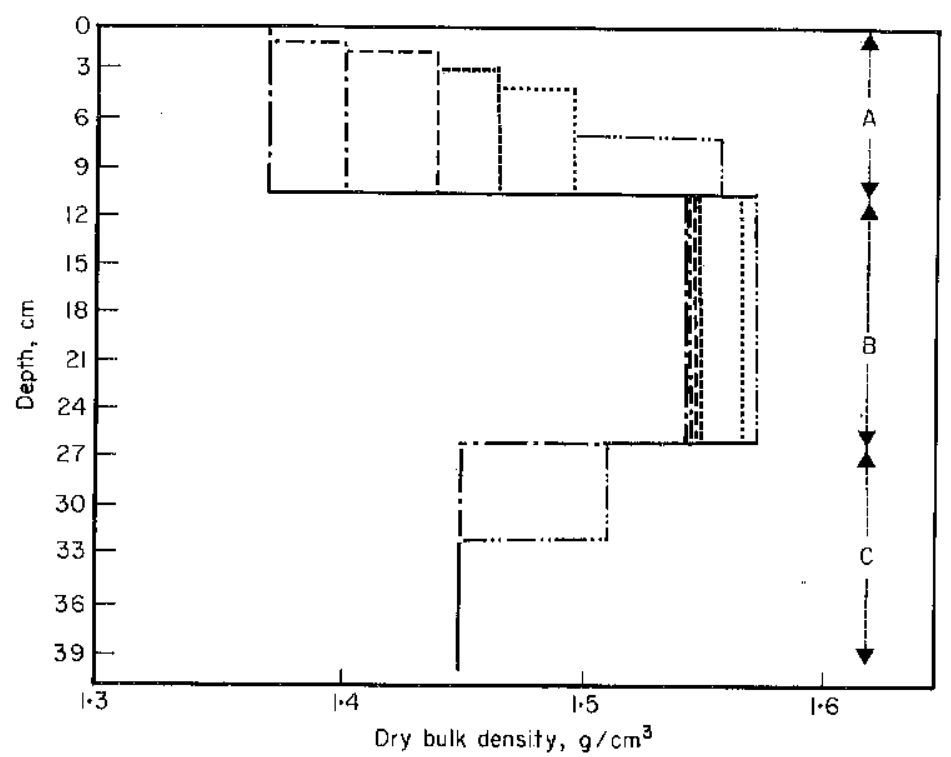

Fig. 5. Development of the bulk density profile with increasing pressure. -..-, Initial;-.-, $200 \mathrm{kPa} ;--\cdots, 300 \mathrm{kPa}$; $\cdots \cdots, 400 \mathrm{kPa} ; \cdots \cdots, 600 \mathrm{kPa} ;-\cdots-, 800 \mathrm{kPa}$

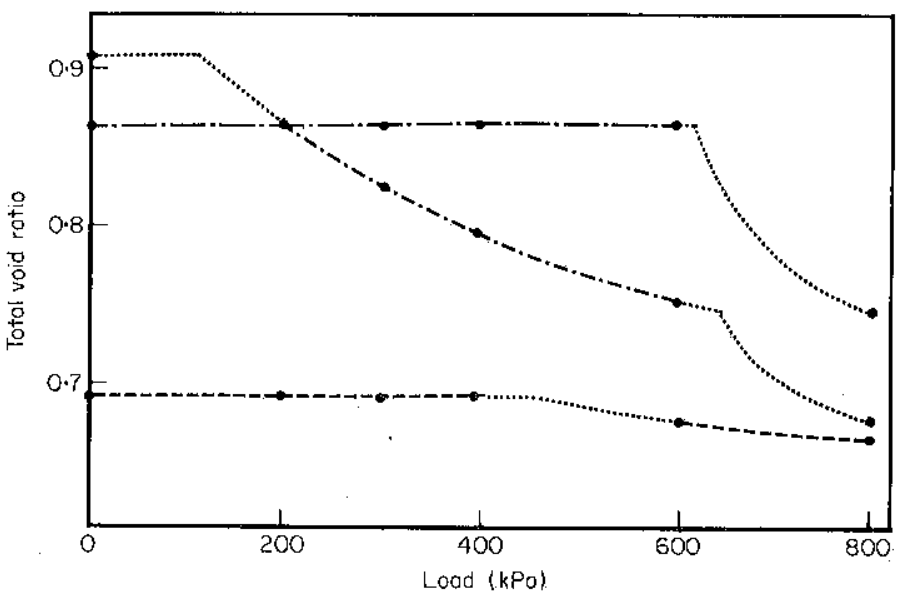

Fig. 6. Compression curves of each layer. ---, A layer;---, B layer; -.--, C layer

The dry bulk density of each defined layer is considered as the mean of values obtained at those depth intervals included in that layer. The measurements at $3 \mathrm{~cm}$ and $9 \mathrm{~cm}$ are both influenced by their proximity to the limits of the layer, the soil-atmosphere interface and the interface between layers A and B, respectively. The dry bulk density of layer A is in fact more homogeneous than is indicated by the measured values. The imposed pressures referred to subsequently are the soil-plate contact pressures.

Fig. 5 shows the development of the profile for each step of compression. Reducing the profile to a three-layer system allows a simplified description and a rough modelling of the compression process. In Fig. 6, the in situ compression curves of each layer are compared (i.e. mean void ratio of each layer versus soil-plate contact pressure). 
The compressibility of the whole profile is a combination of the relative compressibilities of each layer. In the first stage, the compressibilities of layers $B$ and $C$ are nil or negligible compared with the compressibility of layer A. Compaction of layer A increases with pressure. The compression of layer B starts when layer A is sufficiently rigid to transmit the pressure required and is dependent on the degree of initial compactness of layer $\mathbf{B}$. The same interaction is observed between layers B and C.

\section{Discussion and conclusion}

A slight topsoil drying prior to wheeling seems to enhance the effectiveness of low-pressure tyres in preventing excess compaction. The resulting increase in bearing capacity may give only an apparent increase of trafficability and may be a harmful phenomenon, for instance in the case of seedbed wheelings. Field observations showed that the penetration of the dry clods in the uppermost part of the wet layer can result in an increase in bulk density at the interface of the two layers. The resulting soil strength increase at this interface could be an impediment to seedling establishment, particularly for spring-sown crops.

The field compaction test developed in this paper seems to offer a fruitful approach to modelling the compaction process of discontinuous and anisotropic soil profiles provided that they can be considered as multilayered systems. The problem of spatial variability encountered when comparing replicates of bulk density profiles in and between wheel tracks is avoided by measuring changes in bulk density at the same location.

However, several questions remain unanswered and solutions are required to solve technical problems. For example the comparison between bulk density changes and sinkage measurements shows a lateral extension of the compacted zone. This has been confirmed by field observations. Mapping the cone resistance in the vertical cross sectional plane of the compacted zone should enable evaluation of this feature. Also when a pronounced sinkage occurs, the interface depth between two layers may vary and complicate the interpretation of the dry bulk density profiles. In the case of a soil with a water-content variation with depth, sinkage will induce a distortion of the water profile. Water content is an element in the calculation of dry bulk density and, therefore, if the whole compaction test is to be carried out at the same location it will be necessary to have a non-destructive method for measuring water content profile at each step of compression.

Further studies are necessary to investigate the behaviour of different multilayer systems according to the relative thickness of the layers, the relative structure of the layers characterized by their bulk density (or structural void ratio), soil strength and clod size distribution and the relative water content of the layers, each layer being defined by its structural homogeneity and isotropy. Assuming that in most agricultural conditions soil profiles may be considered as multilayers, it should be possible to establish some classification of soil behaviour based on the characteristics of their layers and their behaviour when subjected to compressive forces. To allow deterministic modelling of the process the most essential further study would define the force systems developed in multilayer systems and their interaction with anisotropy.

\section{REFERENCES}

1 Soane, B. D. (Ed.) Compaction by agricultural vehicles: a review. Tech. Rep. 5, Scot. Inst. agric. Engng, 1983

2 Chancellor, W. J. Compaction of soil by agricultural equipment. Bull. 1881, Divn agric. Sci., University of California at Davis, 1976

3 Blackwell, P. S. A method for predicting dry bulk density changes of field soils beneath wheels of agricultural vehicles. Ph.D. Thesis, University of Edinburgh, 1979 (unpubl.)

4 Kuipers, H. Confined compression test on soil aggregates samples. Int. Symp. Soil Structure, Ghent, 1958 349-357 
${ }_{5}^{5}$ Larson, W. E.; Gupta, S. C.; Useche, R. A. Compression of agricultural soils from eight soil orders. Soil Sci. Soc. Am. J., 198044 450-457

6 Faure, A. A new conception of the plastic and liquid limits of clay. Soil Till. Res., 1980/1981 197-105

7 Gućrif, J. Compactage d'un massif d'agrégats: effet de la teneur en eau et de la pression appliquée. Agronomie, 19822 (3) 287-294

8 Fekete, A. Studies of the soil compacting effect of tyres. Mezögazd. gépesit. Tanulm., $19721916-28$

9 Blackwell, P. S.; Soane, B. D. A method of predicting bulk density changes in field soils resulting from compaction by agricultural traffic. J. Soil Sci., $19813251-65$

10 Soane, B. D.; Campbell, D. J.; Herkes, S. M. Hand held gamma-ray transmission equipment for the measurement of bulk density of field soils. J. agric. Engng Res., 1971 16 146-156

11 Stengel, P.; Gabilly, Y.; Gaudu, J. C. La double sonde gamme LPC-INRA: utilisation à des fins agronomiques. Buil. Grpe fr. d'Humid. neutron., 1984 (in press)

12 Fies, J. C.; Stengel, P. Densité texturale des sols naturels: I. Méthodes de mesure; 11. Eléments d'interprétation. Agronomie, $1981 \mathbf{1}(8) 651-658 ; 659-666$

${ }^{13}$ Stengel, P. Swelling potential of soil as a criterion of permanent direct drilling suitability. Proc. 9th Conf. Int. Soil Till. Res. Org., Osijek, Yugoslavia, 1982 131-136 